\section{Hepatitis-C Virus Prevalence in District Shangla and Evaluation of Screening Tests for Anti-HCV}

\author{
Jehangir Khan ${ }^{1, *}$, Rasheedullah', Bakht Tarin Khan ${ }^{2}$, Ayaz Ahmad ${ }^{3}$, \\ Muhammad Salman ${ }^{4}$ and Khalid Khan ${ }^{5}$ \\ ${ }^{1}$ Zoology Department, University College of Science Shankar, Abdul Wali Khan \\ University, Mardan, Khyber Pakhtunkhwa \\ ${ }^{2}$ Department of Zoology, The University of Buner, Buner, Khyber Pakhtunkhwa \\ ${ }^{3}$ Department of Biotechnology, Garden Campus, Abdul Wali Khan University, \\ Mardan, Khyber Pakhtunkhwa \\ ${ }^{4}$ Department of Microbiology and Biotechnology, Abasyn University of Peshawar, \\ Peshawar, Khyber Pakhtunkhwa \\ ${ }^{5}$ Project Director of W omen University, Swabi, Khyber Pakhtunkhwa
}

\begin{abstract}
A B S T R A C T
An estimated 11 million Pakistani individuals are infected with hepatitis and the disease is constantly increasing. Every $10^{\text {th }}$ Pakistani is believed to be suffering from viral hepatitis. It is the first study documenting the epidemiology of HCV in District Shangla, Khyber Pakhtunkhwa (KPK). Blood samples from 900 individuals of various age groups were collected (August to November 2013) from patients at clinics, houses and pharmacies belonging to three Tehsils (Puran, Alpuri and Besham) of district Shangla. The Immuno-chromatographic (ICT) and enzyme linked Immunosorbant Assay (ELISA) techniques were applied for the presence of anti-HCV, while RT-PCR was used for active HCV infection. Our study reports an overall prevalence of HCV among 131 (14.55\%), 103 (11.44\%), and 94 (10.4\%) by ICT, ELISA, and RT-PCR techniques in individuals belonging to 5 different age groups. The RT-PCR based results showed 53\% HCV infection rate in samples from Tehsil Puran, 23\% in Alpuri and 18\% in Besham. The gender wise result (non-significant) showed $10 \%$ and $10.7 \%$ active $\mathrm{HCV}$ infection rates in males and females respectively. The RT-PCR based result observed maximum infection (14\%) in individuals of 4150 years and minimum $(2.7 \%)$ in individuals of $10-20$ years. The ICT resulted in poor screening for HCV infections. The main route of $\mathrm{HCV}$ transmission in males is the sharing razors $(33.33 \%)$, while in females, is the reuse of contaminated syringes ( $42 \%)$ at maternity homes respectively. These alarming results call for initiation of an emergency based awareness campaign about HCV among the public of district Shangla to prevent the impending epidemics of HCV. Additionally, for proper and actual results, the ELISA and RT-PCR techniques are suggested to be recommended instead of ICT for screening the blood against $\mathrm{HCV}$. This work will provide the active HCV prevalence data for further research/studies, which can be helpful to health policy makers to plan strategies for the control of hepatitis $\mathrm{C}$ disease particularly in district Shangla and generally in Pakistan.
\end{abstract}

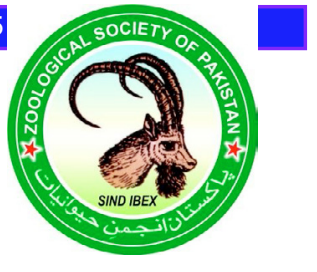

CrossMark

\section{INTRODUCTION}

$\mathrm{A}$ pproximately $130-150$ million people in the world are infected with HCV (Aziz et al., 2015). Statistics based on general healthy population of different countries reveal that $\mathrm{HCV}$ has $7.7 \%$ seroprevalence rate in Zimbabwe, 2.2\% in Turkey and 6\% in Pakistan (Munir et al., 2010; Ilyas and Ahmad, 2014). Moreover, reports based on different parts of Pakistan has revealed that the $\mathrm{HCV}$ infection prevalence is $5.31 \%$ in Islamabad,

\footnotetext{
Corresponding author: abu_amna2013@hotmail.com 0030-9923/2018/0004-1299 \$ 9.00/0

Copyright 2018 Zoological Society of Pakistan
}

$20.6 \%$ in Faisalabad, $16 \%$ in Lahore, $23.8 \%$ in Gujranwala, $0.4-31.9 \%$ in various other areas of Punjab province, $4-6 \%$ in Sindh province, $1.1-9 \%$ in KPK province, $1.5 \%$ in Quetta region of Baluchistan Province, and 25.7\% in Gilgit Baltistan Province (Ilyas and Ahmad, 2014; Anwar et al., 2013).

Hepatitis $\mathrm{C}$ is a viral infectious disease of liver caused by Hepatitis $\mathrm{C}$ virus belonging to family Flaviviridae, and consists of positive sense single-stranded RNA genome (9600 nucleotides) identified in 1989. Contaminated blood, blood products and body fluids are common sources of HCV transmission (Aziz et al., 2015; Ilyas and Ahmad, 2014). Other risk factors include intravenous drug abuse, use of barber razor, dental procedures, 
tattooing, ear piercing, acupuncture and high-risk sexual behavior (Khan et al., 2011). Surveys conducted on the means of transmission of $\mathrm{HCV}$ in different geographical regions of Pakistan have determined the use of needles/ syringes $(61.45 \%)$, major/minor surgery/dental procedures (10.62\%), blood transfusion and blood products (4.26\%), sharing razors during shaving or circumcision by barbers (3.90\%), piercing instruments, nail clippers, tooth brushes, and in less than $1 \%$ due to needle stick, from infected mother to baby and sexual transmission with minor differences in percentage ratios (Idrees and Riazuddin, 2008; Naoman et al., 2013; Saleha et al., 2014).

The confirmation of HCV infection in Pakistan is normally done on the basis of detecting the circulating antibodies (ICT and ELISA) during Laboratory diagnosis (Khan et al., 2011). However, PCR is a more reliable technique for viral RNA detection in the sera of HCV patients due to its accuracy, sensitivity, and specificity compared to ICT and ELISA (Arshad et al., 2013). Much research has been carried out on the epidemiology of $\mathrm{HCV}$ in other parts of the province (KPK), but till now no attention has been given to district Shangla where people are lacking the basic facilities like education and health etc. and do not know about the spread and causes of dreadful diseases like HCV. With the purpose of investigating the epidemiology of active HCV infection and analyzing the scope of antibody-based HCV detection, we screened 900 blood samples for anti-HCV or HCV RNA by ICT, ELISA and PCR.

\section{MATERIALS AND METHODS}

\section{Description of the study area}

District Shangla is a newly born district of Khyber Pakhtunkhwa, Pakistan. The district is bounded in the north by Kohistan District, in the east by Battagram District and the tribal area of Kala Dhaka (Black Mountain of Hazara), in the west by Swat District, and in the south by Buner District. It has an area of $1586 \mathrm{~km}^{2}$ with a population of 512,212 . The socio-economic indicators of Shangla are comparatively low. The literacy rate is $14.5 \%$; for male $25 \%$ and for female $3.7 \%$. Shangla has the lowest human development index in the province and second lowest in the country.

\section{Study type and sampling strategies}

The nature of this study is descriptive and analytical. A random sampling (August to November, 2013) was conducted in the study area. A total of 900 suspected individuals bearing symptoms (pain and tenderness in the area of the liver, fever, joint and muscle pain, decreased appetite, weight loss, depression, jaundice (yellowing of the skin and whites of the eyes) and fatigue) similar to HCV infection were approached at clinics, houses and pharmacies in Besham, Alpuri and Puran. The individuals could be easily accessed at these spots. Out of 900 individuals, $600(66.6 \%)$ were female while $300(33.3 \%)$ were male. A predesigned questionnaire was filled by all the volunteers, carrying information of age, gender, socioeconomic status and various risk factors.

\section{Ethical approval}

Signed consent of all the individuals involved in the study was received before enrollment, while the consent of the parents was recorded for all volunteers under 18. The study and associated protocols were designed based on national ethical legislative rules and approved by Local Ethic Committee of Zoology Department, Abdul Wali khan University Mardan (AWKUM), Buner Campus Khyber Pakhtunkhwa.

\section{Blood sampling and testing}

A $4 \mathrm{ml}$ blood sample was collected in EDTA tubes from each individual randomly involved in the study. The blood was centrifuged to isolate the serum. The serum was further processed for ICT, ELISA and PCR according to the recommended protocols. Standard procedures for reducing contamination were strictly followed.

\section{Immuno-chromatographic test (ICT)}

Five categories of all the individuals were made on the basis of their ages. The serum were isolated and tested by Immuno-chromatographic test (ICT) for anti-HCV antibodies by using ICT strips from Accurate (Accurate Diagnostics, USA). The relative sensitivity and specificity of HCV testing kits was $96.8 \%$ and $99 \%$, respectively.

\section{ELISA for $\mathrm{HCV}$}

All the sera by immuno-chromatographic test were processed further by using $3^{\text {rd }}$ generation enzyme linked immunosorbant assay (ELISA) (DRG Instruments, Germany) kits using the methodology described in the manufacturer's manual.

\section{Detection of HCV RNA through reverse transcriptase PCR}

In order to figure out the actual infection of $\mathrm{HCV}$, qualitative PCR was performed; RNA extraction was carried out using Favorgine RNA extraction kit according to the manufacturer's instructions and protocols adopted by Khan et al. (2011).

\section{Reverse transcriptase PCR}

After extraction of HCV RNA from $200 \mu 1$ serum, the RNA was subjected to make cDNA by using RT-PCR. The 
recipe for RT-PCR was HCV RNA $10 \mu \mathrm{l}$, 5x buffer $4 \mu \mathrm{l}$, dNTPs (10 Mm) $2 \mu$, Outer Anti-sense primer (10 pM) 2 $\mu \mathrm{l}$, reverse transcriptase enzyme $(\mathrm{M}-\mathrm{MLV}, 200 \mathrm{U} / \mu \mathrm{l}) 1 \mu \mathrm{l}$, distilled water $1 \mu$ l. Conditions for RT PCR were $42^{\circ} \mathrm{C}$, $92^{\circ} \mathrm{C}$ and $22^{\circ} \mathrm{C}$ for 40,2 and $2 \mathrm{~min}$, respectively.

\section{Regular PCR}

The cDNA was amplified through nested primers. PCR mix consisted of the following proportions: RT-PCR product (cDNA) $4 \mu \mathrm{l}, 10 \mathrm{x}$ buffer $2 \mu \mathrm{l}, \mathrm{MgCl}_{2}(950 \mathrm{Mm})$ $2.4 \mu \mathrm{l}$, dNTPs $(500 \mu \mathrm{M}) 1 \mu \mathrm{l}$, outer sense primer $\mathrm{C} 1(10$ PM) $1 \mu$, outer anti sense primer C2 (10 PM) $1 \mu$ l, distilled water $7.6 \mu \mathrm{l}$, Taq DNA polymerse $(2 \mathrm{u} / \mu \mathrm{l}) 1 \mu \mathrm{l}$, total 20 $\mu$ l. Alongside, we run the control group as standard to avoid any false results. The thermal profile of PCR was: denaturation step at $95^{\circ} \mathrm{C}$ for $3 \mathrm{~min}$ followed by 35 cycles of $94^{\circ} \mathrm{C}$ for 45 seconds, $54^{\circ} \mathrm{C}$ for 45 seconds and $72^{\circ} \mathrm{C}$ for 60 seconds and final extension step at $72^{\circ} \mathrm{C}$ for $10 \mathrm{~min}$ followed by $4^{\circ} \mathrm{C}$ for $2 \mathrm{~min}$.

Table I.- Prevalence of anti-HCV antibodies and HCV RNA in different age groups.

\begin{tabular}{lcccc}
\hline $\begin{array}{l}\text { Age } \\
\text { group }\end{array}$ & $\begin{array}{c}\text { No of } \\
\text { sample }\end{array}$ & $\begin{array}{c}\text { Anti-HCV } \\
\text { antibodies } \\
\text { positive }\end{array}$ & $\begin{array}{c}\text { Anti HCV } \\
\text { (ELISA) } \\
\text { positive }\end{array}$ & $\begin{array}{c}\text { HCV RNA } \\
\text { positive }\end{array}$ \\
\hline $10-20$ & 110 & $8(7.2 \%)$ & $5(4.5 \%)$ & $3(2.7 \%)$ \\
$21-30$ & 270 & $30(13 \%)$ & $24(8.9 \%)$ & $23(8.5 \%)$ \\
$31-40$ & 150 & $33(17 \%)$ & $25(16.6 \%)$ & $22(11.5 \%)$ \\
$41-50$ & 200 & $36(18 \%)$ & $29(14.5 \%)$ & $28(14 \%)$ \\
51 above & 170 & $24(14 \%)$ & $20(11.7 \%)$ & $18(10.5 \%)$ \\
Total & 900 & $131(14.5 \%)$ & $103(11.4 \%)$ & $94(10.4 \%)$ \\
\hline
\end{tabular}

\section{RESULTS}

The 450 (300 female and 150 male) blood samples were collected from Puran and 250 (150 females and 100 male) from Alpuri while the remaining 200 (150 females and 50 males) blood samples were from Besham. The initial screening of all the blood samples $(n=900)$ by ICT revealed a total of $131(14.55 \%)$ samples positive for anti-HCV antibodies. The ICT positive samples were further analyzed by ELISA, which indicated 103 (11.44\%) samples positive for anti-HCV antibodies. The positive samples by either ICT or ELISA were processed further for HCV RNA extraction and subsequent RT-PCR. The RT- PCR assay revealed the positivity of 94 (10.4\%) samples for HCV RNA (Tables I, II). The samples found negative after repeated screening by ICT/ELISA were discarded and only the positive samples were processed. We used the immune-chromatographic strips from two different sources and each sample was tested twice for confirmation.
Table II.- Tehsil wise distribution and comparison of results by ICT, ELISA and RT-PCR.

\begin{tabular}{lcccc}
\hline Tehsil & $\begin{array}{c}\text { Blood } \\
\text { samples }\end{array}$ & ICT & ELISA & RT-PCR \\
\hline Puran & 450 & $71(15.8 \%)$ & $57(12.7 \%)$ & $53(11.8 \%)$ \\
Alpuri & 250 & $32(12.8 \%)$ & $24(9.6 \%)$ & $23(9.2 \%)$ \\
Besham & 200 & $28(14 \%)$ & $22(11 \%)$ & $18(9 \%)$ \\
Total & 900 & $131(14.55 \%)$ & $103(11.44 \%)$ & $94(10.4 \%)$ \\
\hline
\end{tabular}

Table III.- Sex-wise distribution of $\mathrm{HCV}$ positive samples.

\begin{tabular}{lcccc}
\hline Sex & $\begin{array}{c}\text { No of } \\
\text { sample }\end{array}$ & $\begin{array}{c}\text { Anti-HCV } \\
\text { antibodies } \\
\text { (ICT) }\end{array}$ & $\begin{array}{c}\text { Anti HCV } \\
\text { (ELISA) }\end{array}$ & $\begin{array}{c}\text { HCV RNA } \\
\text { (RT-PCR) }\end{array}$ \\
\hline Male & 300 & $40(13.3 \%)$ & $23(7.7 \%)$ & $30(10 \%)$ \\
Female & 600 & $91(15.1 \%)$ & $80(13.3 \%)$ & $64(10.7 \%)$ \\
Total & 900 & $131(14.5 \%)$ & $103(11.44 \%)$ & $94(10.4 \%)$ \\
\hline
\end{tabular}

Our study indicated high infection rate of $\mathrm{HCV}$ in females (232/600) as compared to males (93/300) (Table III). It has been observed during the study that most of the females were using the contaminated needles for piercing the nose and ears and this was the second most causing source of $\mathrm{HCV}$ among the female population of the area which has not been reported from any other area of the Province. A lot of female practitioners were also observed to use a single contaminated syringe and unsterile instruments at maternity homes and dental clinics which were the main factors for maximum HVC infection in females. Similarly, the males were often observed for their shaves with contaminated blades in the barber shops (Table IV). Some of the workers at barber shops were asked for the reason of using and reusing of already used blades during shave revealed that poverty and cost/expensiveness are the major causes. In comparison with previous studies conducted in the region this study is unique in finding of such types of HCV causing sources among the public. The aforementioned two sources could be the possible cause of high infection rates of $\mathrm{HCV}$ among the public of district Shangla.

The entire result showed anti $\mathrm{HCV}$ antibodies in $131(14.5 \%)$ individuals by ICT, $103(11.44 \%)$ by ELISA followed by PCR which confirmed only 94 (10.4\%) of HCV infections (Tables I, II), our result is one of the highest reports documented from the rest of KPK. Among all the probable modes (Table IV) of HCV transmission observed in the current study, the multiple use of contaminated medical needles/syringes in females and Sharing razors in 
males have caused $42 \%$ and $33.4 \% \mathrm{HCV}$ infections, while the piercing instruments, nail clippers, tooth brushes, from infected mother to baby and sexual transmission observed to account only for less than $1 \%$. Though there might be other sources of HCV spread reported in literature, we observed only the mentioned risk factors as the root causes of HCV spread in the study area.

Table IV.- Risk factors associated with HCV transmission in males and females.

\begin{tabular}{lcc}
\hline Risk factor & Male (300) & Female (600) \\
\hline Reuse of syringes & $30 \%$ & $42 \%$ \\
Surgical instrument & $20 \%$ & $33.3 \%$ \\
Blood transfusion & $15 \%$ & $16.6 \%$ \\
Sharing razors & $33.4 \%$ & 0 \\
Needle stick & $1.6 \%$ & $8.1 \%$ \\
\hline
\end{tabular}

\section{DISCUSSION}

Globally hepatitis $\mathrm{C}$ is an alarming health issue in the least developed and in the developing countries. Since, the epidemiology of the virus is less understood, and the signs and symptoms of the disease are very mild at the onset of infection, therefore, most of the patients come to know about the disease status when it becomes severe and chronic (Arshad et al., 2013). The poor diagnostic (ICT and ELISA) facilities for HCV infections in public hospitals are partly contributing towards the expansion of HCV infection in Pakistan (Khan et al., 2011). The PCR is an excellent tool and comparatively accurate, highly sensitive and more specific than the serological methods (ICT and ELISA). Therefore, PCR should be used for the detection of HCV for accurate results at public health centers. Though we do not discourage the use of ICT and ELISA in the health care centers where the facility of PCR is lacking as these are cheap and quick process, the use of PCR could be strongly recommended.

Although, several studies have been carried out in various parts of Khyber Pakhtunkhwa (Aslam and Aslam, 2001), but none of them have targeted the population of district Shangla for the determination of active $\mathrm{HCV}$ infection. Our study, therefore, is the first of its kind, focusing the HCV risky population of the district. In the current study we attempted to investigate the active $\mathrm{HCV}$ infection employing the standard protocols used for screening and determination of HCV RNA in the patient serum. In this research, out of $14.5 \%$ (ICT result), $10.4 \%$ of the HCV infection was confirmed by PCR (Table I), which is one of the highest reports from various parts of the country. Previously, other studies have also documented high rates of anti-HCV antibodies in individuals from KPK (Arshadi et al., 2012). A more recent report from Peshawar documented the maximum $(13.4 \%) \mathrm{HCV}$ infection in general population in the age group of 21-30 years (Ilyas and Ahmad, 2014). The infection rate observed here is highest (14\%) in the age group of 41-50 followed by 31 $40(11.5 \%)$ (Table I), which is in congruent with Afridi et al. (2013). The high epidemiology of HCV among elders (41-50 years) suggests for the adaptation of self-protecting strategies to reduce the burden of this disease and to stop further spread among the healthy individuals. During this study we also observed those who were shaving by themselves at homes had either less or no HCV infection. This further advice either to avoid shaving in barber shops or at least the shaver should be directed to replace/change the blades previously used. The low prevalence of HCV in males as compared to females was again due to the minimum barber shops in the study area.

Our findings observed minimum HCV infection in the individuals of 10-20 years than those above 20 years which is in complement with other regional studies (Akhtar et al., 2004). One of the reasons for lower HCV infection in the younger may be the limited exposure to various risk factors of HCV infection. This study also shows gender wise result of active $\mathrm{HCV}$ infection with occurrence of $\mathrm{HCV}$ in females (235/600) and males (93/300), respectively (Table III). A number of national and international studies (Ilyas and Ahmad, 2014; Khan et al., 2011; Naoman et al., 2013; Arshad et al., 2013; Ohno et al., 2007) have earlier revealed that male population has comparatively higher infections of HCV than the females but in the current study the female population has higher' $(10.7 \%)$ infection rate than male $(10 \%)$ which is not much significant. Our results are supported by Khan et al. (2014). This difference might be due to unqualified female practitioners using unsterile devices during female's delivery cases at maternity homes and piercing of female nose/ears. The absence of door step education and awareness about HCV infections have led to the increased infection rate of $\mathrm{HCV}$ in district Shangla as compared to other parts of KPK. In the current study, the PCR based result $(10.4 \%)$ is lower than $13.4 \%$ as reported by Ilyas and Ahmad (2014), 62.5\% reported by Arshad et al. (2013) from Peshawar, 20.8\% reported by Khan et al. (2013) from Baluchistan and 23.5\% reported by Khan et al. (2014) from Islamabad, but higher than 4.9\% reported by Anwar et al. (2013) from Lahore and 5\% reported by Naoman et al. (2013) from Peshawar. Here we documented HCV infection (RT-PCR) higher in the age group of 41-50 years (14\%) followed by 31-40 age group $(11.5 \%)$ (Table I). This result is in agreement with Khan et al. (2014) but incompatible with research studies reporting higher infection in individuals of 21-30 years (Ilyas and Ahmad, 2014; Khan et al., 2013; Shaikh et al., 2009). 
Table V.- The previous research reports on HCV epidemiology in Khyber Pakhtunkhwa.

\begin{tabular}{|c|c|c|c|c|c|c|}
\hline \multirow[t]{2}{*}{ Study area } & \multirow{2}{*}{$\begin{array}{c}\text { Study } \\
\text { sample size }\end{array}$} & \multirow[t]{2}{*}{ Positive (\%) } & \multirow{2}{*}{$\begin{array}{l}\text { Method } \\
\text { used }\end{array}$} & \multicolumn{2}{|c|}{ Sex wise distribution } & \multirow[t]{2}{*}{ Reference } \\
\hline & & & & $\hat{0}$ & q & \\
\hline District Peshawar & 982 & $160(16.3 \%)$ & PCR & 84 & 43 & Ilyas and Ahmad (2014) \\
\hline District Mardan & 700 & $63(9 \%)$ & ICT & 41 & 22 & Srivastava et al. (2009) \\
\hline District Mansehra & 400 & $14(3.5 \%)$ & PCR & 300 & 100 & Ali et al. (2010) \\
\hline Various parts of KPK and FATA & 7148 & $224(3.13 \%)$ & ICT, PCR & NA & NA & Khan et al. (2011) \\
\hline District Balakut (Batagram) & 648 & $66(10.3 \%)$ & ICT & 254 & 394 & Jamil et al. (2010) \\
\hline District Buner & 6,000 & $387(6.45 \%)$ & ICT & 186 & 201 & Nawaz et al. (2014) \\
\hline Southern parts of KPK & 25944 & $1352(5.2 \%)$ & ICT & 554 & 296 & Khan et al. (2011) \\
\hline District Mardan & 215 & $177(82.3 \%)$ & PCR & 89 & 88 & Afridi et al. (2013) \\
\hline Different areas of KPK & 167 & $26(15.6 \%)$ & ICT, PCR & 104 & 63 & Ali et al. (2011) \\
\hline Selected districts of KPK & 3075 & $2055(66.7 \%)$ & ICT & 1200 & 855 & Ali et al. (2013) \\
\hline Different areas of KPK & 174 & $130(74.7 \%)$ & ICT, PCR & 104 & 60 & Ahmad et al. (2012) \\
\hline District Swat & 4680 & $220(4.7 \%)$ & PCR & 2870 & 1810 & Ahmad et al. (2009) \\
\hline
\end{tabular}

A number of reports (Anwar et al., 2013; Khan et al., 2013) on epidemiology of hepatitis $C$ virus in various parts of Pakistan have documented the middle age (31-40) with maximum $\mathrm{HCV}$ infection. Moreover, our results are within the range of previously published reports from KPK with some differences as shown in Table V. The occurrence of hepatitis $\mathrm{C}$ virus RNA in the age group $>50$ was $10.5 \%$ in the current study which is lower than the $14.6 \%$ reported by Ilyas and Ahmad (2014). The HCV infection is associated with different routes of transmission. The probable modes of HCV transmission observed in the current study have been shown (Table IV). Our results (about modes of HCV transmission) is comparable with a number of studies (Ilyas and Ahmad, 2014; Idrees and Riazuddin, 2008; Naoman et al., 2013; Saleha et al., 2014; Wazir et al., 2008) with no significant differences in percentages. We recorded mostly the data from patients with known route of HCV transmission.

Majority of the research reports are relying only on the detection of antibodies against $\mathrm{HCV}$, but we carried out ELISA and RT-PCR based HCV RNA detection to record the actual $\mathrm{HCV}$ infection. In this study, screening of blood by ICT devices revealed $14.5 \%$ positivity of the individuals for anti-HCV. As the false positivity by ICT devices is a common problem (Khan et al., 2011; Srivastava et al., 2009), we analyzed all the ICT positive sera by ELISA which indicated 103 (11.44\%) of the blood samples positive for antibodies against HCV (Tables I, II). Twenty eight $(21 \%)$ individuals who were positive by ICT were figure out as negative by ELISA. Our results revealed that screening of blood by ICT devices may not clear the true picture of anti-HCV prevalence. For more precise results, we investigated all the ELISA positive samples by RT-PCR which resulted $10.4 \%$ of the samples as positive for the presence of HCV RNA (Tables I, II). In our province, screening of the blood at maximum health care centers is carried out with ICT devices only (Khan et al., 2011). We suggest that RT-PCR should replace ICT procedures or at least ELISA should be adopted instead of ICT for screening the blood. The disagreement observed among ICT, ELISA and PCR in current research has also been previously reported from Pakistan (Khan et al., 2011; Arshadi et al., 2012).

\section{CONCLUSION}

The present study reports the epidemiology of active $\mathrm{HCV}$ infection (10.4\%) in district Shangla, which is one of the higher results reported previously from the country. The ICT device for screening anti-HCV may not be very authentic. HCV diagnosis should include RT-PCR or at least ELISA procedures for actual result. A campaign about the awareness of HCV infections is critically needed among the public of district Shangla otherwise it may lead to more devastating conditions as the current study observed. Appropriate preventive measures should also be taken into consideration to control the spread of this dreadful disease. Proper epidemiological studies and treatment strategies should be adopted in the area. The workers in laboratories at health care centers need to be trained upon the new techniques and tools for proper diagnosing the diseases like HCV etc. Furthermore, we also suggest directing the unqualified practitioners (males/ females) as well as the workers at barber shops to avoid the 
usage of unsterile blades, syringes and instruments/devices etc which are the main sources of HCV transmission as observed in this study.

\section{ACKNOWLEDGEMENTS}

We are highly thankful to the participants and those who helped us in collecting the data.

Statement of conflict of interest

Authors have declared no conflict of interest.

\section{REFERENCES}

Afridi, S.Q., Zahid, M.N., Shabbir, M.Z., Hussain, Z., Mukhtar, N., Tipu, M.Y., Akhtar, F. and Yaqub, T., 2013. Prevalence of HCV genotypes in district Mardan. Virol. J., 10: 90. https://doi. org/10.1186/1743-422X-10-90

Ahmad, A., Ahmad, B., Ali, A. and Ahmad, Y., 2009. Seroprevalence of HBsAg and anti-HCV in general healthy population of Swat district with frequency of different HCV Genotypes. Pak. J. med. Sci., 25: 744-748

Ahmad, B., Ali, S., Ali, I., Azam, S. and Bashir, S., 2012. Response rates of standard interferon therapy in chronic HCV patients of Khyber Pakhtunkhwa (KPK). Virol. J., 9: 18. https://doi. org/10.1186/1743-422X-9-18

Akhtar, S., Younus, M., Adil, S., Jafri, S.H. and Hassan, F., 2004. Hepatitis C virus infection in asymptomatic male volunteer blood donors in Karachi, Pakistan. J. Virol. Hep., 11: 527-535. https://doi.org/10.1111/ j.1365-2893.2004.00518.x

Ali, A., Ahmad, H., Ali, I., Khan, S., Zaidi, G. and Idrees, M., 2010. Prevalence of active hepatitis c virus infection in district Mansehra, Pakistan. Virol. J., 7: 334. https://doi.org/10.1186/1743-422X-7-334

Ali, I., Siddique, L., Rehman, L.U., Khan, N.U., Iqbal, A., Munir, I., Rashid, F., Khan, S.U., Attache, S., Swati, Z.A. and Aslam, M.S., 2011. Prevalence of HCV among the high risk groups in Khyber Pakhtunkhwa. Virol. J., 8: 296S. https://doi. org/10.1186/1743-422X-8-296

Ali, S., Ahmad, B., Ali, I. and Mahmood, N., 2013. Frequency of active HCV infection among anti$\mathrm{HCV}$ positive patients in selected districts of Khyber Pakhtunkhwa, Pakistan. J. Microbiol. Infect. Dis., 3: 199-202. https://doi.org/10.5799/ ahinjs.02.2013.04.0108

Anwar, M.I., Rehman, M., Hassan. and Iqbal, M., 2013. Prevalence of active hepatitis $\mathrm{C}$ virus infections among general public of Lahore, Pakistan. Virol. J., 10: 351. https://doi.org/10.1186/1743-422X-10-351 Arshad, A., Khan, H.U., Farzana., Aslam, M.S., Rehman, T., Arshad, M., Ahmed, M.S., Ali, I. and Saljoqi, A.R., 2013. Seropositivity and active HCV infection in patients from Peshawar Division of Khyber Pakhtunkhwa Province, Pakistan. Pakistan J. Zool., 45: 1579-1584.

Arshadi, A., Arshad, M., Pervaiz, R., Farzana., Javed, A., Ahmad, N.D. et al., 2012. Prevalance of active Hepatitis-C infection in the general population of district Mardan, Khyber Pakhtunkhwa, Pakistan. $J$ Publ. Hlth. Biol. Sci. 3-8. 1: 3-8.

Aslam, M. and Aslam, J., 2001. Seroprevalance of the antibody to hepatitis $\mathrm{C}$ in selected groups in Punjab region of Pakistan. J. clin. Gastrol., 33: 407-411.

Aziz, H., Raza, A., Ali, K., Khattak, J.Z., Irfan, J. and Gill, M.L., 2015. Polymorphism of the IL28B gene (rs8099917, rs12979860) and virological response of Pakistani hepatitis $\mathrm{C}$ virus genotype 3 patients to pegylated interferon therapy. Int. J. Infect. Dis., 30: 91-97. https://doi.org/10.1016/j.ijid.2014.09.021

Idrees, M. and Riazuddin, S., 2008. High prevalence of hepatitis $\mathrm{C}$ virus infection in the largest Province of Pakistan. Digest. Dis., 9: 96-104. https://doi. org/10.1111/j.1751-2980.2008.00329.x

Ilyas, M. and Ahmad, I., 2014. Chemiluminescent micro particle immunoassay based detection and prevalence of $\mathrm{HCV}$ infection in district Peshawar Pakistan. Virol. J., 1: 127. https://doi. org/10.1186/1743-422X-11-127

Jamil, M.S., Ali, H., Shaheen, R. and Basit, A., 2010. Prevalence, knowledge and awareness of hepatitis c among residents of three union councils in Mansehra School of Public Health and Community Medicine. J. Ayub med. Coll. Abbottabad., 22: 192196.

Khan, A., Tareen, A.M., Ikram, A., Rahman, H., Wadood, A., Qasim, M. and Khan, K., 2013. Prevalence of HCV among the young male blood donors of Quetta region of Baluchistan, Pakistan. Virol. J., 10: 83. https://doi.org/10.1186/1743-422X-10-83

Khan, J., Shafiq, M., Mushtaq, S., Ayaz, S., Ullah, R., Naser, M., Fouad, H. and Abdul Wasim, M., 2014. Seropositivity and coinfection of hepatitis B and C among patients seeking hospital care in Islamabad, Pakistan. BioMed Res. Int., 2014: Article ID 516859. https://doi.org/10.1155/2014/516859

Khan, M.S., Majeed, A., Ullah, S. and Sajjad, M., 2011. An alarming situation in southern part of Khyber Pakhtunkhwa. Annls. Pak. Inst. med. Sci., 7: 228232. 
Khan, M.S.A., Khalid, M., Ayub, N. and Javed, M., 2004. Seroprevalence and risk factors of hepatitis $\mathrm{C}$ virus (HCV) in Mardan, NWFP. Rawal med. J., 29: $57-60$.

Khan, N.U., Ali, I., Ahmad, A.N.U., Iqbal, A., Rehman, L.U., Munir, I. Rehman, M.U., Khan, S., Ali, S., Siddique, L. and Swati, Z.A., 2011. Prevalence of active HCV infection among the blood donors of Khyber Pakhtunkwa and FATA region of Pakistan and evaluation of the screening tests for anti-HCV. Virol. J., 8: 154. https://doi.org/10.1186/1743422X-8-154

Munir, S., Saleem, S., Idrees, M., Tariq, A., Butt, S., Rauff, B., Hussain, A., Badar, S., Naudhani, M., Fatima, Z., Ali, M., Ali, L., Akram, M., Aftab, M., Khubaib, B. and Awan, Z., 2010. Hepatitis C treatment: Current and future perspectives. Virol. J., 7: 296. https://doi.org/10.1186/1743-422X-7-296

Naoman, M., Hussain, M.M., Ali, G., Ishaq, M.S., Khan, M., Salman, M.M., Muhammad, A., Javed, K. and Parvez, A., 2013. Frequency and risk factors of Hepatitis B and Hepatitis C in Peshawar Khyber Pakhtunkhwa. Khyber J. med. Sci., 6: 262-267.

Ohno, O., Mizokami, M., Wu, R.R., Saleh, M.G., Ohba, K., Orito, E., Mukaide, M., Williams, R. and Lau, J.Y., 2007. New hepatitis C virus (HCV) genotyping system that allows for identification of HCV genotypes. 1a, 1b, 2a, 2b, 3a, 3b, 4, 5a, and 6a. J. clin. Microbiol., 35: 201-207.

Saleha, S., Kamal, A., Ullah, F., Khan, N., Mahmood, A. and Khan, S., 2014. Prevalence of hepatitis C virus genotypes in District Bannu, Khyber Pakhtunkhwa, Pakistan. Hep. Res. Treat., 10: 5. https://doi.org/10.1155/2014/165826

Shaikh, F., Naqvi S.Q.H., Jilani, K. and Memon, R.A.D., 2009. Prevalence and risk factors for hepatitis C virus during pregnancy. Gomal J. med. Sci., 7: 8688.

Srivastava, A.V., Czerska, B., Williams, C., Alesh, I., Krese, L., Huang, M.A., Drost, C., Smith, C., Nemeh, H., Tita, C., Brewer, R. and Lanfear, D., 2009. High rates of false-positive hepatitis $\mathrm{C}$ antibody tests can occur after left ventricular assist device implantation. J. Heart Lung Transpl., 28: 159-160. https://doi.org/10.1016/j. healun.2008.11.274

Wazir, M.S., Mehmood, S., Ahmed, A. and Jadoon, H.R., 2008. Awareness among barbers about health hazards associated with their profession. J. Ayub med. Coll. Abbottabad, 20: 35-38. 